\title{
Saving the endangered Native Victoria Tilapia, Oreochromis variabilis Boulenger (1906), in Upper Victoria Nile
}

\author{
Samuel Bassa ${ }^{1, *}$, Erick Ochieng Ogello ${ }^{2}$, Albert Getabu ${ }^{3}$, Laban Musinguzi ${ }^{1}$, Herbert \\ Nakiyende $^{1}$, Mark Olokotum ${ }^{1}$, Henry Ocaya ${ }^{1}$, Stephen Sekiranda ${ }^{1}$, Joseph Nyaundi ${ }^{4}$, Anthony \\ Taabu Munyaho ${ }^{5}$, John Stephen Balirwa ${ }^{1}$
}

${ }^{1}$ National Fisheries Resources Research Institute, Jinja, Uganda. ${ }^{2}$ Department of Fisheries and Natural Resources, Maseno University. ${ }^{3}$ Department of Fishery and Aquatic Studies, Kisii University. ${ }^{4}$ Kenya Marine Research Institute. ${ }^{5}$ Lake Victoria Fisheries Organization, Uganda. *Corresponding author. (c)+256-772-648717 @ basssam2018@gmail.com

\begin{abstract}
This study investigated the catch estimates, mortality, growth, food and feeding habits, and water parameters of Oreochromis variabilis in Upper Victoria Nile (UVN) from 2008 to 2019. Catch rates ranged $0.32 \pm 0.08$ to $3.42 \pm 1.13 \mathrm{~kg}$, boat ${ }^{-1}$, day ${ }^{-1}$ with the length-weight relationship indicating Isometric growth. Growth parameters obtained were $\mathrm{L}_{\infty}=36.75, \mathrm{~K}=0.44 \mathrm{yr}^{-1}, \mathrm{t}_{0}=-0.4540$, $\mathrm{t}_{\max }=6.4$ years, $\varnothing \mathrm{L}=2.774, \varnothing \mathrm{W}=-0.301$. Total mortality $(Z)$ was $1.74 \mathrm{yr}^{-1}$, natural mortality $(\mathrm{M})$ $=0.95 \mathrm{yr}^{-1}$ using riverine surface temperature $(\mathrm{RST})$ of $26^{\circ} \mathrm{C}$ giving a fishing mortality $\mathrm{F}$ of $0.79 \mathrm{yr}^{-1}$ and exploitation ratio (E) of 0.4504 showing that growth parameters concurs with annual estimates and yield $(\mathrm{F}=6.589 ; \mathrm{P} \pm=0.05)$. Catch estimates correlated with water parameters that indicated a significant difference. Mortality parameters showed that the fishery could be experiencing exploitation pressure. Although growth rates revealed that the fish is a long-lived species, if managed properly, its population could recover. Therefore, culturing the species and restocking in rivers and lakes in which this specie was not observed in the East African region are recommended.
\end{abstract}

Keywords: Endangered species, Asymptotic values, Mortality rates, Conservation.

\section{Introduction}

Victoria tilapia, Oreochromis variabilis is one of the native species in the African lakes and rivers (Maithya et al., 2017; Wasonga et al., 2017). It has been, observed as one of endangered species on the African continent like others such as Oreochromis esculentus (Twongo 2006; Maithya et al., 2017; Olwa et al., 2020). Oreochromis variabilis used to be one of the commercially species, fished in Kyoga and the Victoria basin aquatic ecosystems that become rare and now endangered since 1980s (Okaranon 1994; Katunzi and Kishe 2004; Twongo 2006; Ogutu-Ohwayo et al., 2013). Studies have been, undertaken in Kenyan waters of Lake Victoria on how Oreochromis variabilis, could hybridize with other tilapiines species such as, Oreochromis niloticus and Coptodon zilli (Kinaro et al., 2016; Maithya et al., 2017) with a view to increasing the productivity of the tilapiines and conserving the genome in the ecosystem. In addition to that, Oreochromis variabilis 
has been, successfully farmed in controlled ponds environment using formulated diets (Maithya et al., 2017). Despite the fact that these studies are ongoing, there is need for conservation of Oreochromis variabilis in the aquatic ecosystems. Oreochromis variabilis experienced; a large reduction due to high destruction and is believed to be restricted to a few small satellite lakes such as Lake Kimira (FIRRI, Report 2016) and Kabaka's lake (NaFIRRI, report 2020). The species virtually eliminated from its original range in Lake Victoria and Kyoga through predation, competitive aggression and ecological displacement by introduced fish species (Goudsward et al., 2002; Maithya et al., 2017). The Upper Victoria Nile (UVN) has critical habitats where Oreochromis variabilis spawn, feed and undertake growth. Some of these critical habitats are the wetland, rocky areas, sheltered areas (lagoons), inflowing rivers and streams, different types of bottom (rocky, sand muddy), submerged, emergent and floating vegetation (Balirwa et al., 2005; Orina et al., 2018; Bassa et al., 2018; Nkalubo et al., 2018, Bassa et al., 2020). The depth are among features that account for the patchy distribution and variable abundance of fish species in the Victoria Nile. It is likely that river modifications that involved dam construction, nutrient inputs from the nearby industries and agricultural effluents, plus intensive fisheries exploitation could have led to the decline on the Oreochromis variabilis on the Upper Nile (NaFIRRI report 2019).

Food plays a role in the aquatic organism survival, growth, migration patterns and breeding including fish in particular (Nkalubo et al., 2018). In some instances low abundance of the aquatic organisms that are taken as food have led to fish migration patterns from one location to another in search for food within the aquatic ecosystem (Greenwood 1965; Azeroual et al., 2010; Lin 2010; Nkalubo et al., 2018; Ndugutu report 2019). However, some of the drivers that always led to low macro-zoo benthos organism are modifications of the Upper Nile; due to dam constructions and this is backed up with cases such as siltation, lagoon destruction, and loss of sheltered bays thus the alterations of the invertebrate community, migration patterns and changes in fish community structure. In addition to this, pollution and eutrophication of the aquatic ecosystem have led the invertebrate community structure that are one of the food contents for the Oreochromis variabilis species (Mwebaza-Ndawula 1994; Sekiranda et al., 2004; Vincent et al., 2012; Ngupula 2013).

Growth parameters, food interactions and mortality rates gives a prime importance in expressing the dynamics of the Oreochromis variabilis and the fisheries in particular (Abowei et al., 2009; Bassa et al., 2018, Bassa et al., 2019). These parameters tend to determine the total catch and annual amount of fish exploited in the fishery resources (Abowei et al., 2010; Welcomme et al. 2010; Kalhoro et al. 2013)). Several causes of mortality include diseases, pollution, spawning stress and changes in the water levels due to the river modifications (Abowei et al., 2009). Then the exploitation ration (E) enables one assess the stock effectiveness in terms of overfishing. This will always determine the sustainable yield of the fishery. Then, recruitment is the entrance of the young into the exploiting fishing area and become liable to contact with fishing gear. Recruitment is the major source of variability in fish population (Abowei et al., 2010). Then in rivers, habitat destruction, alterations of the ecosystems and unregulated change in water volumes have always led to migrations of the fish stocks and even population collapse or disappearances in intensively regulated stretches (Agostinho et al., 2008). Such cases could be happening on the upper Victoria Nile in the Bujagali stretch area.

In large aquatic ecosystems such as the lakes, habitat destruction had led to environment destruction that lead to fish kills at certain period. Thus, led to a major problem, which could detrimentally affect ecosystem functioning and fish productivity (Sitoki et al., 2010). The Oreochromis variabilis is one the resilient species that has been existing in such environment overtime. Today is one of critically endangered fish species; that need to be under studied in the East African region. Therefore, the main objective this study was to critically, understudy 
the species, by careful scientific research in catches, size structure, growth performance indices, mortality rates and recruitment in relation with the limnology parameters in the ecosystem for biodiversity conservation.

\section{Materials and Methods}

\section{Study Site}

The study was undertaken in the upper Victoria Nile, Bujagali stretch that comprised of ST1 $00.4748^{\circ} \mathrm{N} \& 33.16634^{\circ} \mathrm{E}$ to ST9 $00.50733^{\circ} \mathrm{N} \& 33.13124^{\circ} \mathrm{E}$ (Figure 1) north of the equator.

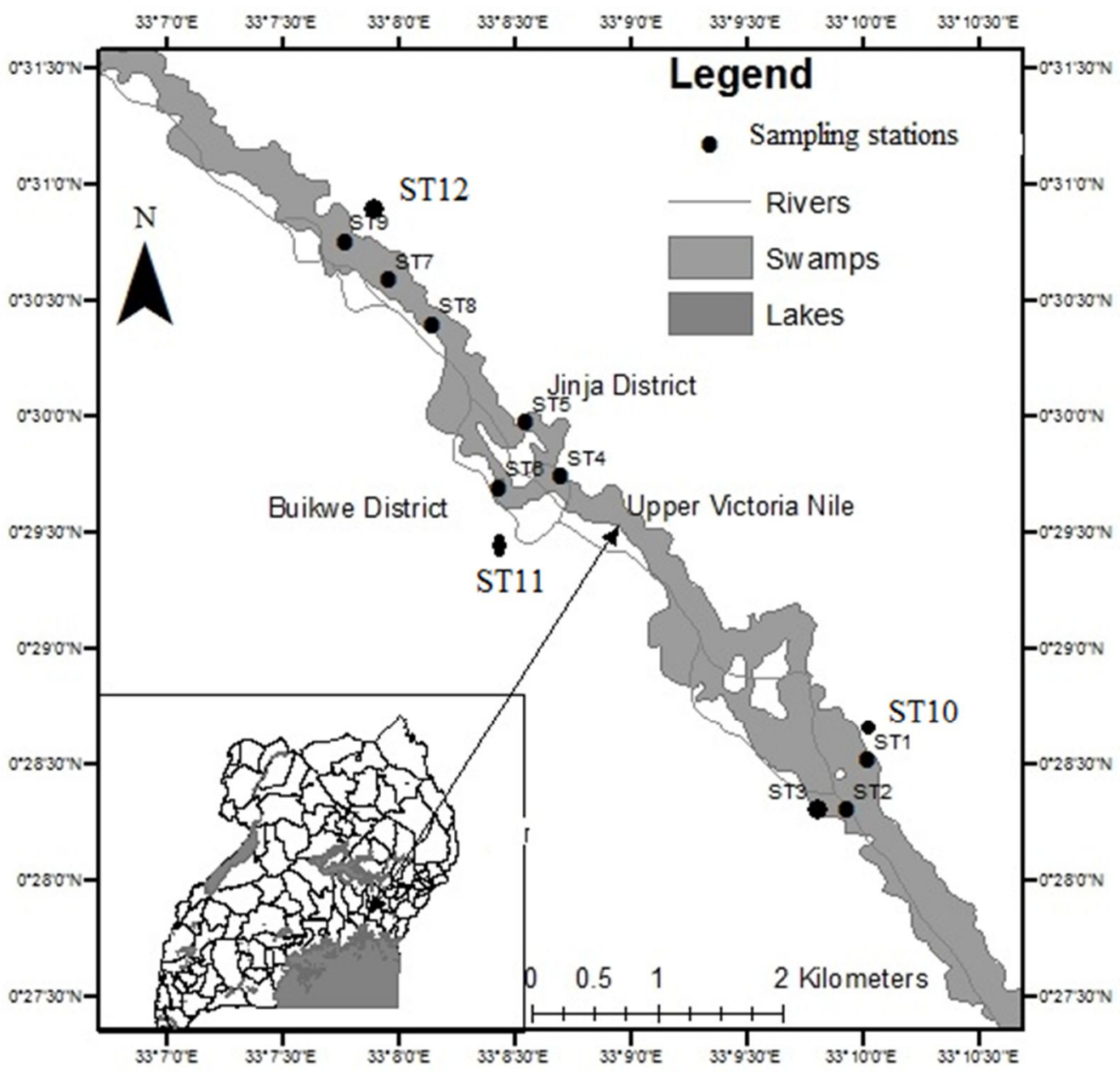

Figure 1. Sampling stations for experimental gillnet, limnology and Catch assessment Upper Victoria Nile.

The sampled sites were nine (9) in number; that were for experimental gillnets in the river. Site selection were done based on the following criteria:- i) Accessibility on either side of the bank 
of the river since not all areas were accessible due to the topography of the banks and very fast flow regime of the river. ii) Status of the fishing activities at the selected site. iii) Proximity upstream or downstream of the developmental projects like hydroelectric power site. iv) Coverage of a wide range of habitats. v) Representativeness of the upper Nile ecosystem. The sample sites defined using a Garmin Satellite Navigator Global Positioning System (GPS) and depth (m) estimated by an echo sounder. Sampling was, conducted bi-annually at nine stations (ST1-ST9) in the UVN during the period 2008 to 2018. Stations (ST1-ST3) had scanty islands in the transects gently sloping banks extensively cultivated with some tree cover of types Tremor orientalis and Ficus species and the margin with Vossia cuspidate macrophytes. Stations (ST4-ST6) were located in the reservoir of the Bujagali hydropower dam with slow moving waters. Steel rolling mills are located about $3 \mathrm{~km}$ from these sites on the Buikwe side in addition to agricultural plantation of both sugarcane and other plants. Stations (ST7-ST9) were located in the downstream of the river below the dam with fast moving waters and rocky at Buyala region (Figure 1).

\section{Physico-chemical parameters}

Water temperature, $\mathrm{pH}$, electrical conductivity and dissolved oxygen were measured in-situ using a Hach Multiprobe meter (HQ40d). Water sample was then collected using a 2-litre horizontal van Dorn sampler into pre-cleaned sample bottles and transported to the laboratory for analysis as described by Stainton (1970) and Wetzel and Likens (2000). In the laboratory, the water sample was, filtered through Whatman GF/C glass fiber filters for analysis of dissolved nutrients. For dissolved nutrients, the filtrates were used in the analysis of Soluble Reactive Phosphorus (SRP) $\left(\mathrm{PO}_{4}-\mathrm{P}\right)$; nitrates $\left(\mathrm{NO}_{3}-\right)$, and ammonia $\left(\mathrm{NH}_{3}\right)$, were determined using the ammonium molybdate method (Wetzel and Likens 2000), sodium salicylate method (Müller and Weidman 1955), and the indophenol blue method according to (Krom 1980) respectively. The data were normalized (mean $=$ zero and standard deviation $=1$ ) and pattern of similarity/differences of environmental data were determined by calculating Euclidean distance. A Principal Component Analysis (PCA) performed on the resemblance matrix to identify the pattern of environmental variables; PERMANOVA used to test the differences in the groupings along the sampling stations using PRIMER7+PERMANOVA.

\section{Fish data collection, sampling and analysis}

Data was, collected from 12 stations, nine of which were, from experimental gillnet and three were catch assessment stations (Figure 1). Experimental sets of gillnets were used to collect fish samples in the identified sampling sites. Gillnets were rectangular in shape, on the upper edge, the head rope had floats and on the footrope with sinkers. Gillnets could either drift or set stationary or in form of gangs of nets of different mesh sizes (Sparre and Venema 1998). Three fleets of gillnets of mesh sizes ranging from 25.4-203 mm to eight (8) (203 mm) in increment of $25.4 \mathrm{~mm}$ up $139.7 \mathrm{~mm}$ then others of $152.4,177.8 \& 203.2 \mathrm{~mm}$ were set in each sampling site. The nets were set at each of the three experimental sampling sites in each sampling locality for the period of two days. They were set in the evening at 6:00 pm and retrieved at $6.00 \mathrm{am}$ in the morning. Fish samples from gillnets were sorted out into species and the mesh size in which they were caught. Individual weight per fish specimen, using electronic balance scale Model CS10KWP-IP65 to the nearest $1 \mathrm{~g}$, since the electronic balance only weighed fish up to the maximum of 5000 gram. A measuring board of 100 centimeters used to measure total and 
standard length to the nearest $0.1 \mathrm{~cm}$. Fish species identification was, done using Greenwood (1966).

In the laboratory, the fish dissected was order to determine sex and observe the type of food eaten. Stomach contents were, preserved in 5\% formalin and analyzed using an inverted microscope model XSZ-H at magnification X50 and X100. The food items identified, and points allotted to different degrees of stomach fullness according to Hynes (1950); Hyslop (1980) and Natarajan, Jhingran (2011) to give stomach fullness index. The contribution of food items relative to all food items in the gut was determined through visual judgment. The sexual maturity stages of 1-6 scored and recorded using the method by Witte and Van Densen (1995) the number of each fish species at each sexual maturity stage identified recorded. This later used to determine the length at which $50 \%$ of the population was mature. Further, the size of the smallest mature fish for both males and females recorded at each sampling. Sexes were determined for only those fish whose gonads were identifiable as male and female and maturity stages of fish assigned from stage I to VI according to a method described by Witte and Van Densen (1995). The length-weight relationship data of Oreochromis variabilis calculated by the power function equation. $\mathrm{W}=\mathrm{aL}$, where "W" is the total weight $(\mathrm{g})$, " $\mathrm{L}$ " is the total length $(\mathrm{cm})$, "a" is the intercept, "b" is the slope (Sparre and Venema 1998; Kalhoro et al., 2013).

Catch assessment (CAS) surveys are dedicated surveys aimed at harvest sector to generate information relating to both fish catches and fishing effort (LVFO 2007b; LVFO 2007c; Bassa et al., 2014). At the selected landing sites, the fishing boats were, stratified by Vessel/boat gear type and the sample boats selected randomly. At the landing sites all boats were, sampled since the sites had less than 20 vessels recommended by the standard operating procedures for the Catch assessment survey. Data collected from the fisher's catches included the fish species, total length (TLcm), total weight $(\mathrm{kg})$, gear type, the number of crew per vessel and the vessel type.

\section{Estimation of growth parameters using FISAT II and ELEFAN methods}

The ELEFAN program was, applied to estimate growth parameters (i.e. Recruitment, length at infinity, maximum age of the fish). The growth parameters estimated were; asymptotic length $\left(L_{\infty}\right)$ and growth coefficients $(K)$. The von Bertalanffy growth models was used to estimate the asymptotic length growth such as asymptotic length and growth coefficient using the equation $\mathrm{l}_{\mathrm{t}}=\mathrm{L}_{\infty}=\left(1-\exp \left(-\mathrm{k}\left(\mathrm{t}-\mathrm{t}_{\mathrm{o}}\right)\right)\right)$ respectively. (Pauly and Morgan 1987; Bassa et al., 2019). The age at birth which is the, $t_{0}$ value was estimated using empirical equation; $\log 10(-t)=-0.3922$ $0.2752 \log _{10} \mathrm{~L}_{\infty}-1.038 \log _{10} \mathrm{~K}$. Then the growth performance in terms of length and weight respectively; $\varnothing=\log \mathrm{K}+2 \log \mathrm{L} \infty ; \varnothing=\mathrm{Log}_{10} \mathrm{~K}+2 / 3 \log \mathrm{W}_{\infty}$; maximum age $\left(\mathrm{t}_{\max }\right)$ estimated as $t_{\max }=3 / k+t_{0}$ (Sparre and Venema 1998; Bassa et al., 2019). The fishing mortality (F) obtained by subtracting natural mortality $(\mathrm{M})$ and total mortality $(\mathrm{Z})$ and exploitation rate $(\mathrm{E})$ was estimated from F/Z. Total mortality $(Z)$ was estimated using length converted catch curve method as implemented in ELEFAN II. Natural mortality (M) was estimated by Pauly empirical formula where by $\ln \mathrm{M}=\left(0.0152-0.279 * \ln \mathrm{L}_{\infty}+0.6543 * \ln \mathrm{K}+0.463 * \ln \mathrm{T}\right)$ with the riverine surface temperature (RST) of $26^{\circ} \mathrm{C}$ (Sparre and Venema 1998; Bassa et al., 2019). 


\section{Results and Discussion}

\section{Water quality parameters}

Principal Component Analysis (PCA) ordination of environmental variables reflected variations along the sampled sites along the river section. The first, second and third axes accounted for $20.6 \%, 14.5 \%$ and $12.0 \%$ of the total variance among the sampled sites (Figure 2). The first axis was negatively associated with dissolved oxygen and $\mathrm{NO}_{3}$-, while the second axis positively correlated with $\mathrm{pH}$ and $\mathrm{PO} 4-\mathrm{P}$.

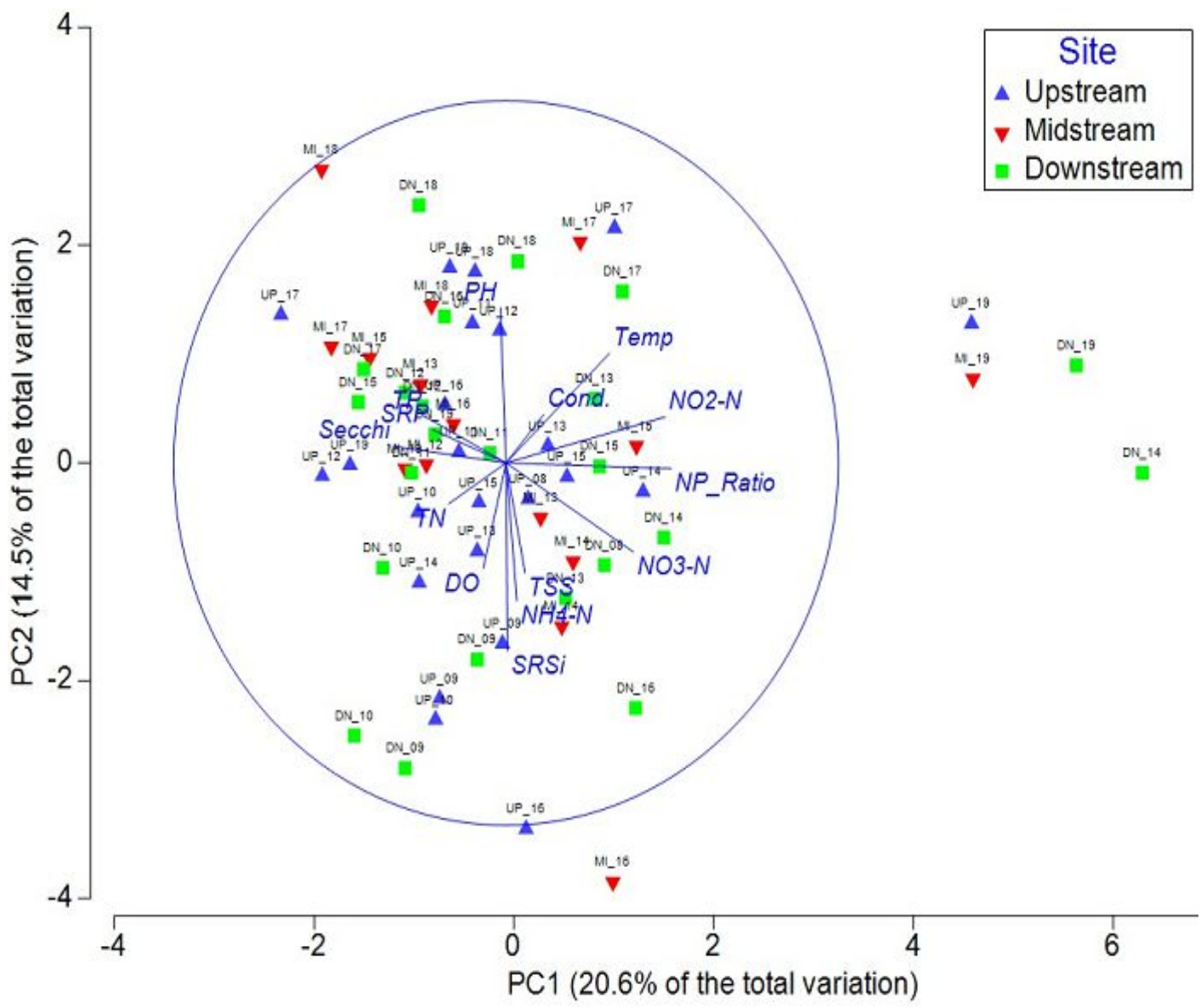

Figure 2. Principal Component analysis (PCA) ordination plot based on environmental variables using Euclidean distances amongst the sites along the variables (Combined datasets 2008-19)

The permutation multivariate analysis of variance (PERMANOVA) indicated that environmental characteristics differed significantly between sites, upstream. Midstream and downstream (Pseudo-F $=0.97608, \mathrm{P}(\mathrm{perm})=0.459,0.105,0.685)$ but these conditions differed over the years Pseudo-F $=2.5998, \mathrm{P}($ perm $)=0.001)$. There was no significant difference resulting from the interaction between annual sampling for the sampled sites along the river section (Pseudo-F $=0.46916, \mathrm{P}(\mathrm{perm})=1)$. Along the gradient in the river section, only the 
DO showed significant differences across the sampled sites $(\mathrm{p}<0.05$, ANOVA). However, over the years, dissolved oxygen, $\mathrm{pH}$, nutrients $\left(\mathrm{NH}_{3}-4, \mathrm{NO}_{2}\right.$ and $\left.\mathrm{TN}\right)$ were significantly different (Table 1). Furthermore, Tukey HSD showed that the differences observed in DO is only due to difference between Upstream - Downstream, and Upstream-Downstream but not Upstream-Midstream.

Table 1. Physico-chemical parameters sampled from the UVN

\begin{tabular}{lllllll}
\hline Station & $\mathrm{DO}(\mathrm{mg} / \mathrm{L})$ & $\mathrm{T}\left({ }^{\circ} \mathrm{C}\right)$ & $\mathrm{pH}$ & Cond. $\left(\mu \mathrm{Scm}^{-1}\right)$ & $\mathrm{NO}_{3}-\mathrm{N}(\mu \mathrm{g} / \mathrm{L})$ & $\mathrm{TP}(\mu \mathrm{g} / \mathrm{L})$ \\
\hline ST1 & $5.79 \pm 0.15$ & $25.91 \pm 0.07$ & $7.17 \pm 0.08$ & $105.28 \pm 2.51$ & $76.81 \pm 4.94$ & $59.67 \pm 2.80$ \\
ST2 & $5.88 \pm 0.11$ & $25.81 \pm 0.06$ & $7.17 \pm 0.06$ & $99.77 \pm 2.50$ & $90.10 \pm 4.82$ & $55.04 \pm 2.45$ \\
ST3 & $5.74 \pm 0.14$ & $25.89 \pm 0.07$ & $7.17 \pm 0.06$ & $100.28 \pm 2.50$ & $79.63 \pm 5.59$ & $55.73 \pm 2.07$ \\
ST4 & $6.13 \pm 0.00$ & $26.60 \pm 0.00$ & $7.05 \pm 0.00$ & $110.00 \pm 0.00$ & $44.49 \pm 0.00$ & $56.97 \pm 0.00$ \\
ST6 & $7.50 \pm 0.00$ & $25.90 \pm 0.00$ & $8.50 \pm 0.00$ & $92.30 \pm 0.00$ & $55.70 \pm 0.00$ & $56.97 \pm 0.00$ \\
ST7 & $6.75 \pm 0.38$ & $26.18 \pm 0.15$ & $7.09 \pm 0.06$ & $106.83 \pm 11.91$ & $63.06 \pm 11.91$ & $59.63 \pm 6.24$ \\
ST8 & $6.54 \pm 0.66$ & $25.75 \pm 0.15$ & $7.45 \pm 0.08$ & $101.50 \pm 49.70$ & $96.60 \pm 49.70$ & $80.40 \pm 33.10$ \\
ST9 & $6.44 \pm 0.21$ & $26.20 \pm 0.03$ & $7.19 \pm 0.03$ & $107.25 \pm 12.60$ & $58.14 \pm 12.60$ & $68.42 \pm 9.98$ \\
\hline
\end{tabular}

\section{Fish catches}

Fishes of Oreochromis variabilis were, recorded from the UVN from both Catch assessment and experimental gillnets mainly in the Bujagali area at bi-annual basis. The catch rates varied from $0.32 \pm 0.08$ to $3.42 \pm 1.13 \mathrm{~kg} / \mathrm{boat} / \mathrm{day}$ and by site, they varied between $1.95 \pm 0.35$ to $4.93 \pm 3.09 \mathrm{~kg} / \mathrm{boat} / \mathrm{day}$ from the catch assessment studies. Then $0.066 \pm 0.012$ to $0.418 \pm 0.0263 \mathrm{~kg} / \mathrm{net} /$ day from the experimental gillnets. In addition to that, size structure data was analyzed in order to observe the trends in catches over time and space. ANOVA test indicated $(\mathrm{F}=5.744 ; \mathrm{P} \pm=0.05)$ in terms of catch rates. The Correlation matrix of person square indicated the value of coefficient $r$ of 0.91 , significant at the 0.05 level (2-tailed). Results from the study sites showed that the Victoria tilapia, total catches varied from $0.81 \pm 0.03$ to $14.80 \pm 0.97$ tons from $2014-2019$ as compared to the previous studies that were $4.04 \pm 0.25$ to 13.08 \pm 0.61 metric tons from $2008-2013$ (Figure 3). 


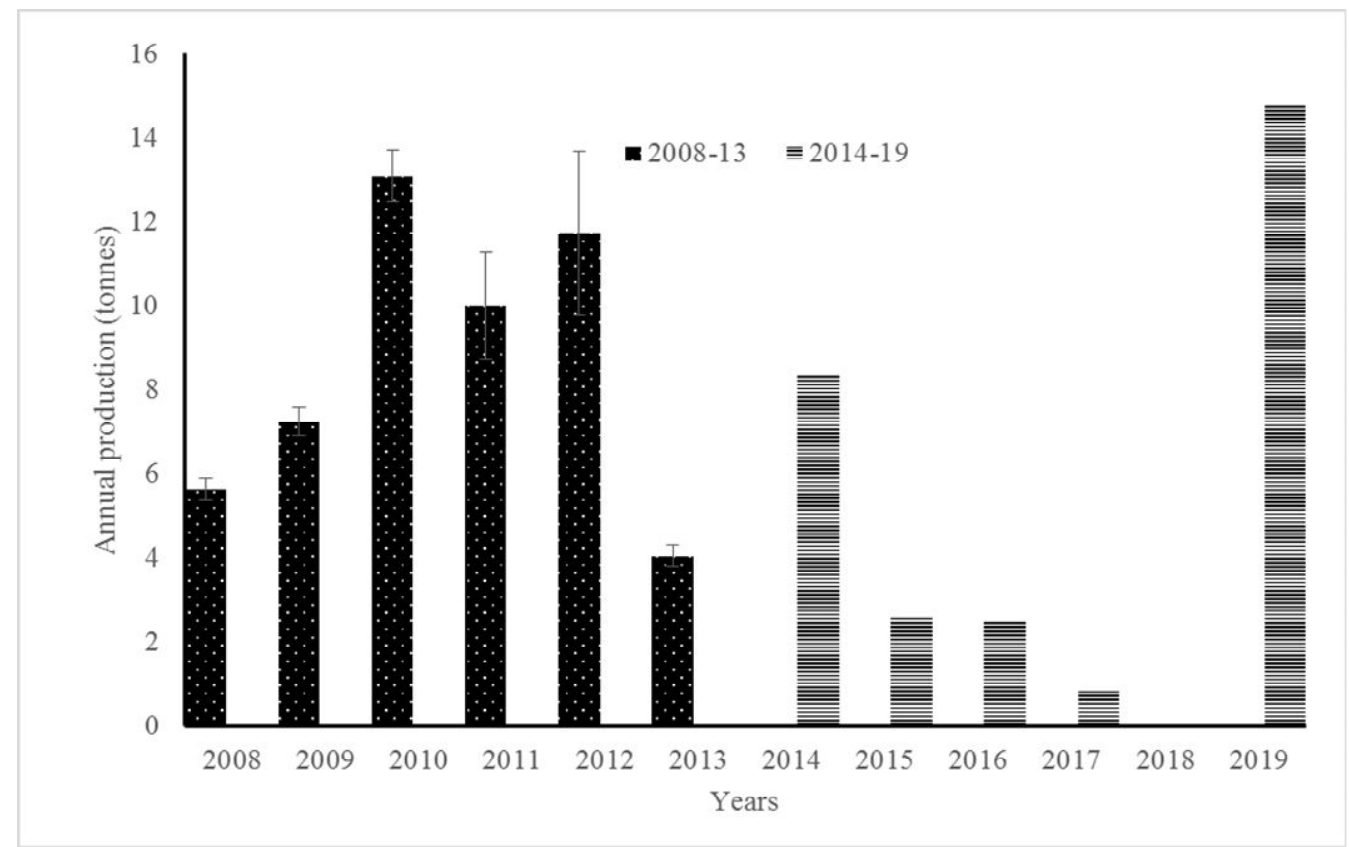

Figure 3. Annual production variations for Oreochromis variabilis from the Catch assessment Survey.

Results from the study sites showed that the total catches of Victoria tilapia varied from $0.81 \pm 0.03$ to $14.80 \pm 0.97$ tons from 2014-2019 compared to the 2008 -2013 study were $4.04 \pm 0.25$ to $13.08 \pm 0.61$ metric tons were reported (Figure 3). Victoria tilapia catches showed a high increase in the year 2019 like other fish species attributed to changes in the weather patterns. T-Test analysis showed a statistically significant difference in the 2.5 and 3.0 inches fishing gears $(\mathrm{P}<0.05)$. However, between, 2008 - 2013, the fishing gears showed a statistically insignificant difference $(\mathrm{P}>0.05)$ for the mesh size sampled.

\section{Length-weight relationship and growth and mortality parameters}

Both sexes male and female pairs of Oreochromis variabilis length and weight ranged from 7.3 (0.01) to $31.0(0.58) \mathrm{cm}(\mathrm{kg})$ respectively. The combination of total length-weight relationship for both sexes was calculated at $W=\operatorname{lnq}+b(\operatorname{lnL}) ; \mathrm{W}=0.000031 \mathrm{~L}^{3.126}\left(\mathrm{R}^{2}=0.9119\right), \mathrm{n}=350$ from experimental gillnet data recorded.

\section{Growth performance indices and Beverton-Holt Yield/Recruit analysis}

Growth parameters, von Bertalanffy growth parameters of Oreochromis variabilis were estimated as $\mathrm{L}_{\infty}=36.75 \mathrm{~cm}$ (TL) and $\mathrm{K}=0.44$ year $^{-1}$. Then $\mathrm{t}_{0}$ and $\mathrm{t}_{\max }$ values calculated were; $\mathrm{t}_{\mathrm{o}}=-0.4540$, $\mathrm{t}_{\max }=6.4$ years respectively. Then with application of length converted catch analysis VBGF growth parameters $(\mathrm{L} \infty$ and $\mathrm{K})$ as input values the estimation of total mortality was recorded at $\mathrm{Z}=1.74$ year $^{-1}, \mathrm{M}=0.95, \mathrm{~F}=0.79 \& \mathrm{E}=0.4504$ year $^{-1}$ then $\mathrm{Lc} / \mathrm{L}_{\infty}=0.5905 \mathrm{M} / \mathrm{K}=2.15901 \mathrm{using}$ the RST of $26^{\circ} \mathrm{C}$ (Figure 4). 


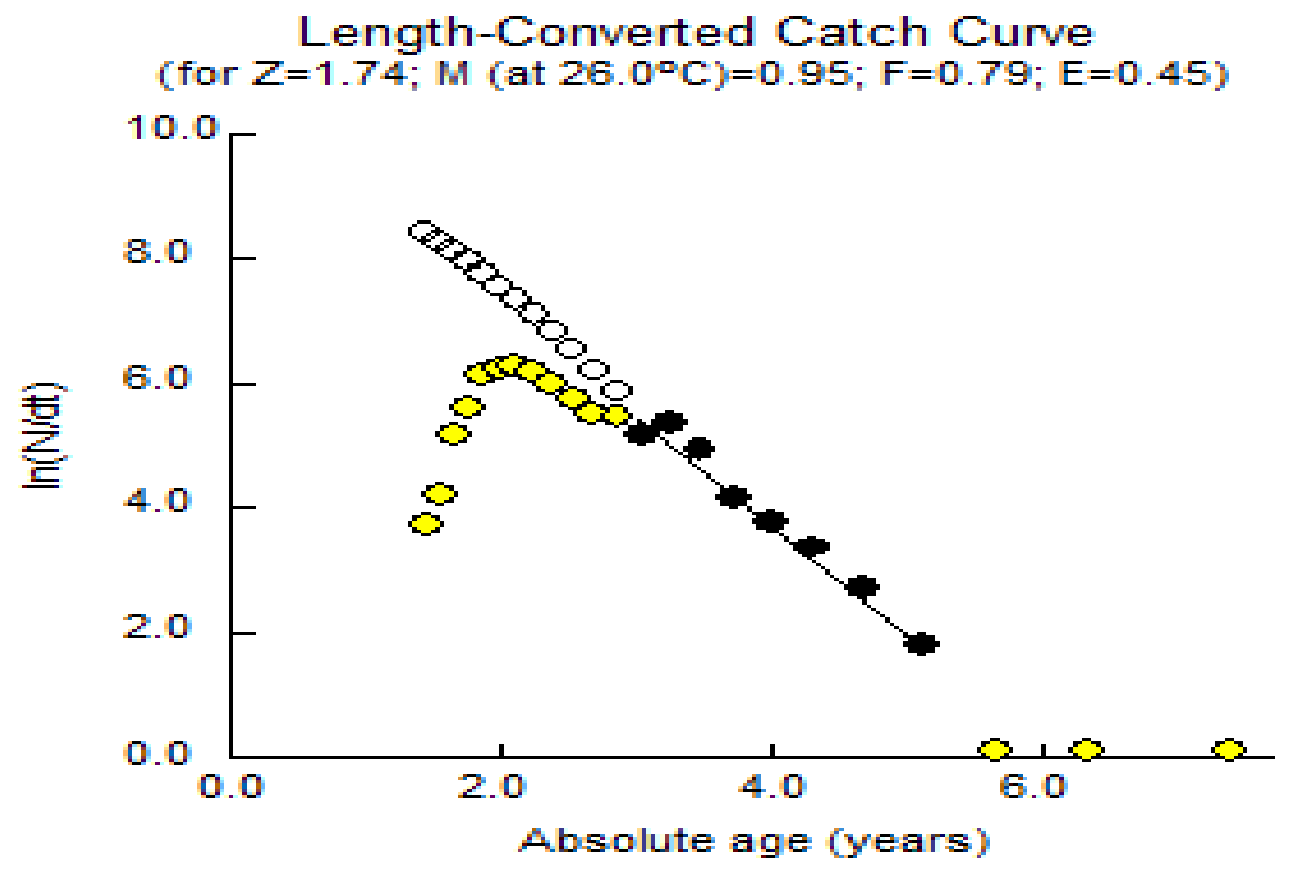

Figure 4. Mortality rates for Oreochromis variabilis from the UVN 

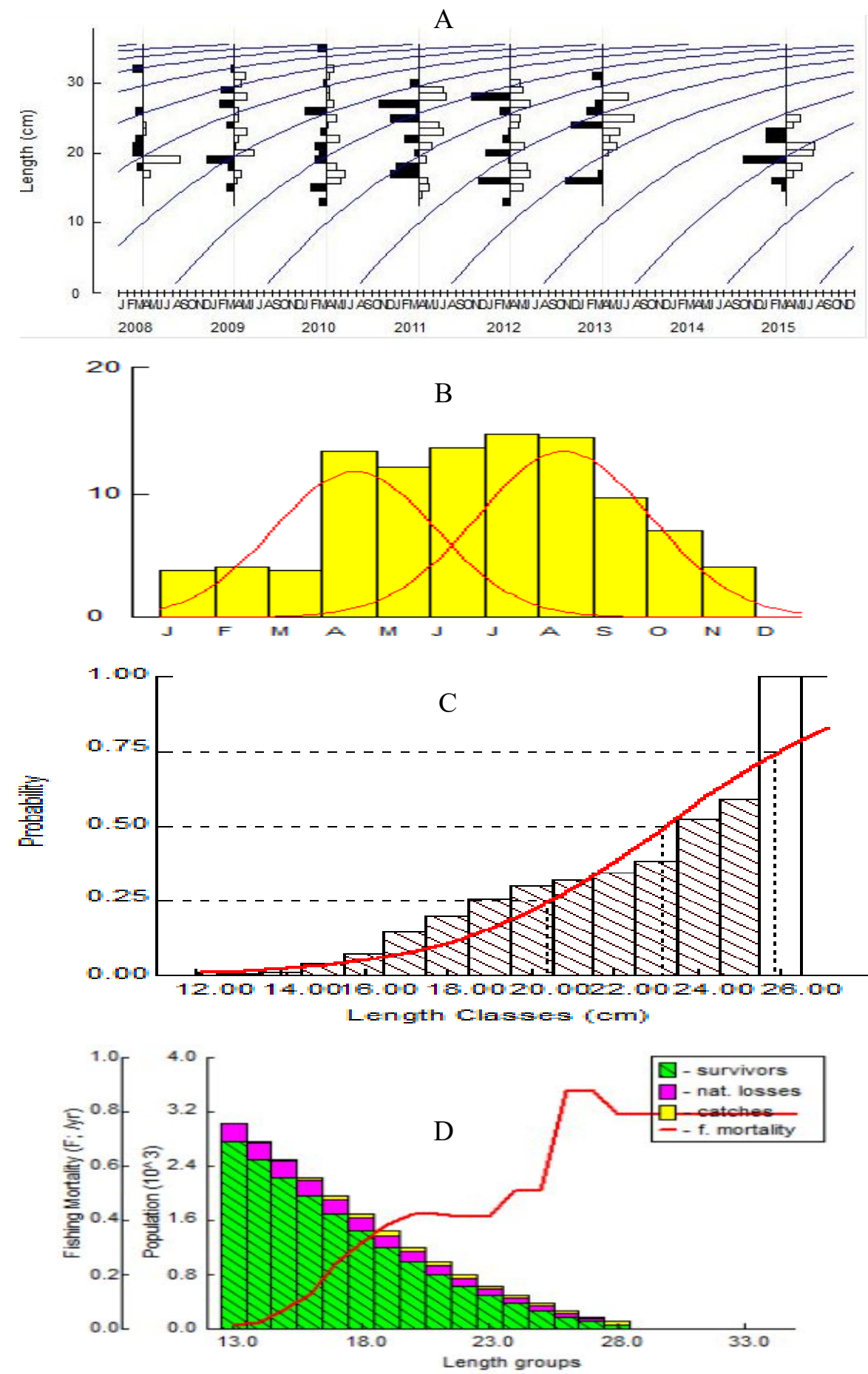

Figure 5. (A)The von Bertalanffy growth curve (VBGF) and length plot. (B) The Recruitment patterns for Oreochromis variabilis from the UVN for the sampled period with patterns of the two-year circle. (C) Probability of capture of Oreochromis variabilis in centimeters Total length sampled from UVN. (D) Length-structures Virtual Population analysis (VPA) on the O.variabilis for the experimental data. 
The growth performance indices asymptotic length $\left(\mathrm{L}_{\infty}\right)$ and asymptotic weight $\left(\mathrm{W}_{\infty}\right)$ were $\varnothing=2.774$ and -0.301 year $^{-1}$ respectively for $2008-2018$. The von Bertalanffy growth models was used to estimate the asymptotic length growth such as asymptotic length and growth coefficient as $\mathrm{L}_{\infty}=36.75 \mathrm{~cm}(\mathrm{TL})$ and $\mathrm{K}=0.44$ year $^{-1}$ respectively. The probability of capture indicated at least $(25 \%)$ of fish of $20.39 \mathrm{~cm} \mathrm{TL},(50 \%)$ of the fish of $23.11 \mathrm{~cm}$ TL and $(75 \%)$ of all fish of $25.84 \mathrm{~cm}$ TL retained on encounter with the gear (Figure 5).

\section{Food and feeding habits and Sex ratios}

Eleven (11) food types identified from the gut contents of the Oreochromis variabilis species. Some of the types included; Macro invertebrates like Tricoptera, Hemiptera, Rotifers, Copepods, Chaobrus larvae, Crabs and the Insect remains. Further, we had other food types that were under the phytoplankton, Detritus, Blue green, Green and Diatoms. The Oreochromis variabilis mainly depended on following food types; Chaobrus larvae (4.08\%), Tricoptera (4.08\%), Insect remains (6.12\%), Hemiptera (4.08\%), Crabs (4.08\%), Detritus (6.12\%), Blue green (22.45\%), Green (20.41\%), Diatoms (14.29\%), Copepods (4.08\%) and Rotifers (4.08\%). The Chisquare $\left(\mathrm{X}^{2}\right)$, test used to tests differences in the diet within and between periods of sampling showed: - Chaobrus larvae $(\mathrm{p} \pm=0.05)$, Tricoptera $(\mathrm{p} \pm=0.05)$. Insect remains $(\mathrm{p} \pm=0.05)$, Hemiptera ( $\mathrm{P} \pm=0.05)$, Crabs $(\mathrm{P} \pm=0.05)$, Detritus $(\mathrm{p} \pm=0.05)$, Blue green $(\mathrm{p} \pm=0.05)$, Green algae ( $\mathrm{p} \pm=0.05)$, Diatoms ( $\mathrm{p} \pm=0.05)$, Copepods ( $\mathrm{p} \pm=0.05)$ and Rotifers $(\mathrm{p} \pm=0.05)$.

The sex ratio for Oreochromis variabilis recorded and showed that for the period sampled, males to females ranged from 1:1 to 2:1. Chi-square test indicated males $\left(\mathrm{X}^{2}, \mathrm{~F}=3.819\right.$, $\mathrm{df}=5$, $\mathrm{P} \pm=0.05)$ and for females $\left(\mathrm{X}^{2}, \mathrm{~F}=33.807, \mathrm{df}=6, \mathrm{P} \pm=0.05\right)$.

\section{Discussion, Conclusion and Recommendations}

\section{Variations in water parameter of Oreochromis variabilis}

The Upper Victoria Nile is a highly influenced section of River Nile mainly due to the existence of several dams. However environmental conditions fall within tolerable levels as compared to Lake Victoria system where this river originates. This justifies that ranges suitable for Oreochromis variabilis life in this ecosystem like as explained by other scientists (Chaurasi and Tiwari 2012; Sharma, et al., 2013; Yadat et al., 2014; WHO 2015; Orina et al., 2018; Bassa et al., 2019). As indicated earlier, Oreochromis variabilis used to be the native tilapia that was highly treasured by the riparian people along the lakes and rivers as source of income and food (Twongo 2006; Maithya et al., 2017) that are now, endangered. This was observed in the variation in the catch rates both spatially and temporal basis. Observations indicated that out of the ten Kyoga basin water bodies it was only one that had recorded Oreochromis variabilis during the study undertaken by (Ogutu-Ohwayo et al., 2015) an indication of the scarce fisheries resource in the ecosystem. Despite of the tolerable environment parameters, the catches have shown low trends apart from one-year yield that might have been a change in the climatic conditions. This kind of trend is unsustainable in the fisheries biodiversity conservation. Therefore, since the water parameters were in the tolerable conditions, it shows mortality and growth parameters indicated that human exploitations could have created high impact on this species disappearance in the ecosystem 


\section{Growth parameters and length-weight relationship}

Observations showed, that length-weight relationship used in fish growth and stock assessment methods. Then the weight ratio between the lengths of the fish is significant for biology of fishes (Kalhoro et al., 2017). The slopes of a and b of Oreochromis variabilis indicated a $=0.0003$ and $b=3.126$ that implied that these fishes were growing isometric form. The present study was compared with other studies $\mathrm{a}=0.06295-0.09218$ and $\mathrm{b}=2.345-2.457$ (Maithya et al., 2017), $\mathrm{a}=0.00707-0.03555, \mathrm{~b}=2.81-3.15$ (Kinaro et al., 2015). The growth parameters indicated that O.variabilis long-lived species that can withstand various conditions effectively. Drivers such as unsustainable exploitation could be an attribute to its hindrance in the vicinity in addition to habitat variations. Therefore, the fishery could exists effectively once protected from such drivers in the ecosystem.

\section{Feeding interactions}

Feeding indicated that these fishes are plankton feeders and due to that the organisms identified from the gut contents, though there were some macro invertebrates observed in that were from bottom strata of the water system. The low density of phytoplankton and macro invertebrates in the ecosystem driven could have been attributed by the modification of the water system and creation of barrages thus by change in the riverine system as hence affect the river continuum (Vannote et al., 1998). Microbial biomass and modified detritus serves as food source for detrivores (both invertebrate and vertebrate) that are common in streams and rivers (Vannote et al., 1998). In such instances, low levels of such food stuffs in the aquatic ecosystem can lead to low catches of the Oreochromis variabilis in addition of the ecosystem overfishing.

\section{Catch variations of the Victoria tilapia (Oreochromis variabilis)}

Oreochromis variabilis, popularly known as Victoria tilapia, is one of the native species in the African lakes and rivers and one of the endangered species in the African continent (Maithya et al., 2016). The habitat for this species used to be the Victoria and the Kyoga basin lakes before introducing the Nile perch (Kudongania and Cordone, 1974; Okaronon, 1994; Bassa et al., 2020). Despite of the critical nature the study observed fluctuation trends in the catches on the Upper Victoria Nile. The UVN is one of the systems in Uganda that habits this species in addition to the Kyoga system. Trends variations show that this species once managed properly the fishery could rejuvenate.

\section{Conclusion and Recommendations}

Since the water parameters were in the tolerable conditions, it shows mortality and growth parameters indicated that human exploitations could have created high impact on this species disappearance in the ecosystem. Therefore, there is need to have sustainable management measures of the Oreochromis variabilis fisheries in order to have the available stocks in the Victoria basin system. Some the measures could be culturing the Oreochromis variabilis and restocking in rivers and lakes in which this species was not observed in the East African region. 


\section{Acknowledgement}

We thank all the NaFIRRI staff who worked on the data collection on the River Nile, Bujagali areas and the fishers who helped us in the experimental net setting activities. Our thanks also go to Bujagali Energy, Uganda limited, Jinja Uganda (BEL) who funded the data collection.

\section{References}

Abowei, J.F.N, George A.D.I and O.A. Davies 2010. Mortality, exploitation rate and recruitment pattern of Callinectes amnicola (De Rochebrune, 1883) from Okpoka, Creek, Niger Delta, Nigeria. Asian journal of agricultural Sciences 2(1): 27-34 ISSN: 2041-3890.

Agostinho, A., Pelicice, F. and L., Gomes 2008. Dams and the fish of the Neotropical region: impacts and management related to diversity and fisheries. Brazilian journal of Biology, 68(4), 1119-1132.

Azeroual, A., Entsua-Mensah, M., Getahun, A., Lalèyè, P. and J., Kazembe 2010. Malapterurus electricus. The IUCN Red List of Threatened Species 2010: e.T182850A7985142. http://dx.doi.org/10.2305/IUCN.UK.2010-3.RLTS.T182850A7985142.en. Downloaded on 20 December 2019.

Bassa S., A. Getabu ,E.O. Ogello, A. M. Taabu , D. O. Owiti, H. Nakiyende, J. S. Balirwa, J.K. Nyaundi, L. Musinguzi, and W.

Nkalubo 2020. Stock Assessment of Lates niloticus in Upper Victoria Nile and its Impact on Uganda's Economy. Uganda Journal of Agricultural Sciences, ISSN: 1026-0919 (Print); 24106909 (Online), Volume 19 Number 2 (2020) pp. 11 - 26, DOI: http://dx.doi.org/10.4314/ujas.v19i2.2,C 2020 National Agricultural Research Organization, https://www.ajol.info/index.php/ujas.

Bassa, S., A. Getabu, D.O. Owiti, A.M. Taabu, E. Ogello, N.E. Orina, L.,I, Muhoozi, R. Olwa, H., Nakiyende, D., Mbabazi., E. K., Muhumuza, J., S., Balirwa and W. Nkalubo 2019. Assessment of the Ecosystem integrity of the Upper Victoria Nile (UVN), East Africa based on Habitat and Fish species biotic indices. Uganda Journal of Agricultural Sciences ISSN: 1092609-6909 (Online), Volume 19 Number 1(2019) pp. 1-17, DOI.

Bassa S. Owiti. D. O., Getabu, A., Nkalubo .W. Nakiyende, H., Balirwa J.S., Natugonza V., and A.M., Taabu 2018. Effects of exploitation pressures and river damming on the population structure of Elephant snout: A case study on the Upper Victoria Nile, East Africa. Uganda Journal of Agricultural Sciences, ISSN: 1026-0919 (Print); 2410-6909 1(18) 1 - 17, DOI: http://dx.doi.org/10.4314/ujas.v18i1.2,C 2018 National Agricultural Research Organisation

Chaurasi, N. K., and R. K., Tiwari 2012. Physico-chemical characteristics of sugar factory and distillery effluents. Annals of Biological Research, 3(9), 4406-4408.

FIRRI, 2016. The study of socio-economic aspects of Lake Kamira fisheries after the ban on fishing. Jinja, Uganda, Fisheries Resources Institute (FIRRI), pp. 1-7.

Hyslop, E. 1980. Stomach contents analysis - a review of methods and their application. Journal of Fish Biology 17(4): 411-429.

Kalhoro, T. M., Yongtong, M., Kalhoro, M.A., Hussain, S.S.B., Mahmood, M.A., Muhammad, A., and P.T. Ramesh 2017. Stock assessment of Indian Scad, Decapterus Resselli in Pakistani 
Marine Waters and its Impact on the National economy. Fisheries and Aquaculture journal. DOI: 10.4172/2150-3508.1000200.

Katunzi E.F.B and M.A. Kishe 2004. Changes in population structure of the major fish species in selected satellite lakes around Lake Victoria following changes in fishing effort. Tanz.J. Sci. 30(2), 53-63.

Kinaro, Z.O., Xue, L., and J.A Volatiana 2016. Complete mitochondrial DNA sequence of the Victoria tilapia (Oreochromis variabilis) and Red belly Tilapia (Tilapia zilli): genome characterization and phylogeny analysis. DOI: 10.3109/19401736.2015.1033695.

Krom, M. D. 1980. Spectrophotometric determination of ammonia: a study of a modified Berthelot reaction using salicylate and dichloroisocyanurate. Analyst, 105(1249), 305-316.

Lin Q., 2010.Influence of Dams on River Ecosystem and Its Countermeasures. Journal of Water Resource and Protection, 2011, 3, 60-66 doi:10.4236/jwarp.2011.31007 Published Online January 2011 http://www.scirp.org/journal/jwarp.

Maithya, J. N.M Mbithi, and P., Wanjala 2017. Growth performance of Oreochromis variabilis larvae: A case study of effect of live and formulated diets growth and survival rates. International journal of Fisheries and Aquaculture. DOI: 10.5897/IJFA2016.0553.

Mwebaza-Ndawula, L. 1994. Changes in relative abundance of zooplankton in northern Lake Victoria, East Africa. Hydrobiologia, 272, 256-264.

Müller, R., and , O. Wiedemann 1955. Die Bestimmung des Nitrations im Wasser. Vom Wasser, 22, $247-271$.

NaFIRRI, 2020. The status of the fish stocks and environment of Kabaka's lake, Jinja, Uganda, National Fisheries Resources Research Insitute (NaFIRRI), 47pp.

NaFIRRI report 2019. Aquatic and Fisheries survey of the Upper Victoria Nile. A report prepared for AES Nile Power Bujagali Hydropower Project.

Natarajan, A. and A. Jhingran 2011. Index of preponderance and method of grading the food elements in the stomach analysis of fishes. Indian Journal of Fisheries 8 (1):54-59.

Ngupula, G. W. 2013. How Does Increased Eutrophication and Pollution in the Lake Victoria Waters Impacts Zooplankton? Journal of Environment and Ecology, 4, 151-164.

Nkalubo, W., Balirwa, J., Bassa, S., Muhumuza, E., Nsega, M. and R., Mageni 2018. Fish breeding areas as a management tool for resources in Lake Victoria, East Africa. African journal of Tropical hydrobiology and Fisheries 16:1-9.Lake Victoria Fisheries Organization.

Greenwood, 1965. Fishes of Uganda. The Uganda society Kampala.

Ogutu-Ohwayo H., K.Ondongkara, W.Okello, D.Mbabazi, S.B. Wandera, L.M.Ndawula and V.Natugonza 2013. Variations and changes in habitat, productivity, composition, composition of aquatic biota and fisheries of the Kyoga lake system: lessons for management. African journal of Aquatic Science. 38 (1), 1-14.

Okaranon J.O. 1994. Current composition, distribution and relative abundance of the fish stock of Lake Victoria, Uganda. The African journal of Tropical Hydrobiology and Fisheries. Vol.5 No.2.

Olwa, R., H. Nakiyende, E. Muhumuza, S. Bassa, A. Taabu-Munyaho and W. Nkalubo 2020. Ecology of the Critically Endangered Singidia Tilapia (Teleostei: Cichlidae: Oreochromis esculentus) of Lake Kayanja, Uganda and its conservation implications. Journal of Threatened Taxa 12(10): 16251-16256. https://doi. org/10.11609/jott.5700.12.10.16251-16256.

Orina, E. N., A., Getabu, R. Omondi and E. Sigel 2018. Ecosystem integrity indices based on Fish diversity and physico chemical parameters in River Kuja, Kenya. Journal of Tropical bydrobiology and Fisheris.1:07-13.

Pauly, D., and D. Morgan 1987. Length-based methods in fisheries research, ICLARM conference Proceedings 13, International Center for living Aquatic Resources Management, Manila and Kuwit Institute for Scientific Research, Saft. 
Sekiranda, S. K. B., Okot-Okumu, J., Bugenyi, F. W. B., Mwebaza-Ndawula, L. and P. Ghandhi 2004. Variation in composition of macro-benthic invertebrates as an indication of water quality status in three bays in Lake Victoria. Uganda Journal of Agricultural Sciences, 9, 396-411.

Vincent, K., Mwebaza-Ndawula, L., Makanga, B. and S. Nachuha 2012. Variations in zooplankton community structure and water quality conditions in three habitat types in northern Lake Victoria. Lakes \& Reservoirs: Research \& Management, 17, 83-95.

Sharma, A., Bora, C. R., and V. Shukla 2013.Evaluation of seasonal changes in physico-chemical and bacteriological characteristics of water from the Narmada River (India) using multivariate analysis. Natural Resources Research, 22(4), 283-296.

Sparre, P., and S., C. Venema 1998. Introduction to tropical fish stock assessment manual. Part 1 Manual FAO Technical paper 306/1 Rev.2. Rome, FAO. 209-210. M-43.ISBN-92-5-103996-8.

Stainton, M. 1970. Standard operating manual for water analysis. University of Manitoba Canada.

Twongo, T.K., Bayona, J.D.R. and M. Hanssen 2006.Oreochromis variabilis. The IUCN Red list of Threatened species 2006:e.T15458A4587788 http://dx.doi.org/10.2305/IUCN.uk2006.RTLS.T15458A4587788.en downloaded on 02 October 2017.

Wasonga A.G., Daniel W.A. and O. Brian 2017. Interspecific hybridization of tilapiine in Lake Victoria, Kenya. Journal of Fisheries and livestock production. DOI: 10 4171/2332-2608, 1000235.

Welcomme R.L. Cowx G.I., Coates D., Bene C., Funge-Smith S., Halls A. and K. Lorenzen 2010. Inland Captures. Phil. Trans. R. Sco B 3635, 2881-2896. Doi:10.1098/rstb.2010.0168.

Wetzel, R. G., and G. E. Likens 2000. Inorganic Nutrients: Nitrogen, Phosphorus, and Other Nutrients. In Limnological Analyses (3rd ed., pp. 87 - 112). New York: Springer.

WHO 2015. UN-Water GlaasTrach Fin Initiative: Tracking financing to sanitation, bygiene and drinking water at the national level. Guidance document summary for decision-makers. Geneva Switzerland, pp. 3-19.

Yadat, A., Jyoti, R., and D. Renu 2014.Physico-chemical analysis of treated and untreated effluents from sugar industry. Journal of environment and human, 1(2), 2373-8332. 